\title{
Albína Dratvová o ženské duši
}

\section{Albína Dratvová on Female Psyche}

\author{
Jan Zouhar
}

\begin{abstract}
Abstrakt
Česká filosofka Albína Dratvová (1892-1969) je připomínána především pro své práce z filosofie prrírodních věd a jako autorka řady učebnic filosofie a logiky pro střední školy. Významnou část jejího myšlenkového odkazu tvoří také publikace antropologicko-etické. Mezi nimi má důležité místo knížka Duše dnešní ženy. Autorka v ní vychází z vlastní zkušenosti a vlastních zážitkư a věnuje se významu a úkolưm duševní činnosti žen v nových podmínkách a formách ženské aktivity. Jemná analýza duševní situace žen je i výzvou a návodem pro nalezení smyslu života.
\end{abstract}

\section{Klíčová slova}

Albína Dratvová, ženská psychika, typologie žen

\begin{abstract}
Czech philosopher Albína Dratvová (1892-1969) is especially remembered for her work in philosophy of natural science and as an author of a number of secondary school textbooks in philosophy and logic. An important part of her intellectual legacy consists of her anthropological-ethical works, most importantly the work Duše dnešni ženy (On the Soul of the Contemporary Woman). The author proceeds from her personal experience and focuses on the role and function of the mental activities of women in new conditions and forms of women's activity. The subtle analysis of the mental situation of women also brings a challenge and directions for finding the meaning of life.
\end{abstract}

\section{Keywords}

Albína Dratvová, female psyche, typology of women 
Albína Dratvová (1892-1969) vystudovala na pražské univerzitě filosofii, fyziku a matematiku. Doktorát z filosofie získala v lednu 1918, vyučovala nejdříve na holešovickém lyceu, od roku 1919 byla středoškolskou profesorkou na dívčím gymnáziu Krásnohorská. Byla autorkou několika středoškolských učebnic filosofie a logiky, zvláště Úvodu do filosofie (1928) a Filosofie (1936), v roce 1928 přešla do pedagogického oddělení Ministerstva školství a národní osvěty a odtud v době německé okupace českých zemí v roce 1942 na vlastní žádost předčasně do výslužby. V roce 1932 se spisem Problém kauzality ve fyzice habilitovala a začala přednášet jako soukromá docentka na Př́rodovědecké fakultě Univerzity Karlovy. O práci Filosofie a přirodovědecké poznání (1939) později Jiřina Popelová napsala: „Způsob, jímž traktovala filosofii přírodovědy, zahrnujíc do ní metodologii, vědosloví, psychologii badatelského procesu i otázky ontologické, noetické a světonázorové, byl její originální koncepcí a má svůj význam jak pro filosofii, tak pro dějiny vědy"1 Dratvová se soustředila na otázky, které si kladou př́rodovědci, jimž zjištění jevů a jejich popis nestačí, a kteří chtějí proniknout blíže $\mathrm{k}$ podstatě věcí. $\mathrm{K}$ této oblasti se vztahují i její práce Heuristické predpoklady fyzikálního bádáni (1934), O aplikabilitě matematiky, Planckova filosofie (1939) a časopisecké studie o předních osobnostech z dějin přírodní vědy a filosofie.

Ve vědomí relativnosti poznání a v nemožnosti vybudovat na přírodovědeckém základě ucelený světový názor nalézala i kořeny soudobého „smutku vzdělanců“. Mezi českými filosofkami má Albína Dratvová v řadě aktivit primát. Byla první ženou, která v české filosofii nastoupila akademickou dráhu, jako první žena se pro obor filosofie habilitovala a jako první žena u nás publikovala filosofickou knižní monografii. Byla respektovanou odbornicí v problematice vztahu filosofie a prrírodních věd a v oblasti logiky. Přesto se po válce marně ucházela o profesuru filosofie na Karlově univerzitě a po roce 1948 jí další práce ve filosofii nebyla umožněna. Její poslední knížka Hledáni ztraceného kosmu (1948) narazila „na komunistické filosofy a ,filosofy“ a způsobila ostré výtky“, ${ }^{2}$ jak si poznamenala do svého Deniku 6. září 1948. O několik dní později si pak přiznala: „... mívám chvíle strachu, že mne vyloučí z university. Ty referáty proti mému poslednímu dílku už byly tři a jejich ostrost se stupňovala."3

1 Jiřina Popelová, Za filosofkou Albínou Dratvovou, Filosofický časopis 18, 1970, č. 4, s. 701.

2 Albína Dratvová, Denik 1921-1961. Scientific Diary, Praha: Academia 2008, s. 414.

3 Tamtéž, s. 415. 
Recenzentem většiny knižních prací Albíny Dratvové byl především Miloš Materna. Ve své recenzi knihy Filosofie a přírodovědné poznáni ${ }^{4}$ si všímá toho, že titul knihy vlastně nevystihuje její vlastní poslání, kterým je podle něho úvodní příručka pro posluchače prrírodovědecké fakulty. Materna ocenil, že autorka „úspěšně formuluje obtížná témata, a podává tak přehlednou, metodickou příručku dobře uvádějící. Kniha je kriticky namířena proti pozitivismu, machismu, novopozitivismu, proti jejich fyzikalismu, antimetafyzičnosti a formalismu. Materna se ovšem domnívá, že autorka ve svém odporu k formalismu zašla přiliš daleko, přitom filosofie matematiky tvoří dodnes důležitý filosofický problém. V přírodovědném poznání lze navíc možná očekávat nové pojetí pravdy, poznání a „revizi poměru dění duševního a neduševního“, přitom „chápání hranic, úkolů a vlastní povahy př́rodověd vyžaduje porovnání s duchovědami“. Dratvová podle M. Materny roste od jedné práce k druhé, recenzovaná kniha sice neoslňuje svéráznými filosofickými ideami, ale „autorka prokázala tímto cenným a hodnotným spisem svoji vysokou odbornou úroveň“.

Kladně Materna posoudil i Dratvové spis Planckova filosofie. ${ }^{5}$ Pokládal ji za přípravnou studii ke knize Filosofie a přirodovědné poznáni. Konstatuje, že autorce je řada Planckových názorů blízká - o metafyzických kořenech vědy, o realismu, v oceňování světa hypotéz, v přísné kritice pozitivismu a jeho formalismu. Materna ocenil i knížku Etika tvưrči práce ${ }^{6}$ Podle něho by se spíše měla jmenovat Morální úvahy o pracovitosti. Vyniká četnými a aktuálními podněty, přesto podle Materny nelze spoléhat „na dobrou vưli, kde se bojuje o spravedlnost proti kořistníkům z cizí práce“ “. ${ }^{7}$ Smysl pracovitosti přináší až kontext $\mathrm{s}$ jinými požadavky na člověka, autorka zjednodušila poměr tvưrčí a netvưrčí práce, blíže se měly zkoumat příčiny nedostatku pracovitosti.

Albína Dratvová využívala životní jubilea velkých vědeckých osobností k připomenutí jejich významu pro filosofii. V roce 1942 se jí takto nabídli Galileo Galilei (300 let od jeho smrti 8. 1. 1642) a Isaac Newton (narodil se 25. 12. 1642). Vysvětlovala jejich vědecké objevy, ocenila jejich zakladatelský přínos vědě a lidstvu, charakterizovala jejich osobnost, geniální schopnost vidět v přírodních jevech zákonitost, střízlivost a metodičnost v myšlení,

4 Miloš Materna, A. Dratvová: Filosofie a přírodovědné poznání, Praha: Unie 1939, 316 s. Česká mysl 35, 1941, č. 1-2, s. 88-90.

5 M. Materna, A. Dratvová: Planckova filosofie. Spisy vyd. Př́rodovědeckou fakultou Univerzity Karlovy, č. 169, 1939, 19 s. Česká mysl 35, 1941, č. 1-2, s. 90-91.

6 M. Materna, A. Dratvová: Etika tvůrčí práce, Praha: Hendrich 1941, 125 s. Česká mysl 35, 1941, č. 4-5, s. 228-229.

7 Tamtéž, s. 228. 
schopnost postavit se proti předsudkům. Všimla si toho, že Galilei znamenal svými nevyvratitelnými pozorováními a výpočty revoluci ve filosofických názorech, jeho myšlení působilo „nápravně na tehdejší filosofy, učilo je, že nad spekulaci platí svědectví pokusu a vlastního pozorování, učilo je skromnosti při řešení obtížných problémů, jakož i odvaze postavit se prostými lidskými silami pevně proti zakořeněným silám, ovládajícím svět". ${ }^{8}$ Dratvové se Newton jeví ,jako filosof doznívající renesance, kde se přírodověda mísila s jemnými, u Newtona matematicko-logickými zkoumáními, jimiž chtěl přírodu svázat v pevný logicko-matematický systém“. 9

O Dratvové psaly naše filosofické časopisy při jejích životních jubilejích a po jejím úmrtí. A tak v prvním čísle 36. ročníku České mysli (leden - únor 1942) redakce připomněla v redakční poznámce padesátiny Albíny Dratvové, „docentky filosofie na Přírodovědecké fakultě české Univerzity Karlovy a vrchní odborové rady v ministerstvu školství“, která se věnuje „usilovné práci o filosofii př́rodních věd" a v poslední době též morálním tématům. ${ }^{10}$ K sedmdesátým narozeninám Albíny Dratvové ocenil v roce 1962 ve Filosofickém časopise Karel Mácha ${ }^{11}$ její působení středoškolské profesorky a zejména docentky filosofie na Karlově univerzitě v meziválečném období, a její práce Problém kauzality ve fyzice a zejména Filosofie a přirodovědecké poznání, ve které „shrnula základní problematiku metodologie filosofie a přírodních věd s důrazem na její noetický a psychologický aspekt“. Karel Mácha se zmínil i o učebnicích filosofie a logiky, které Dratvová napsala pro střední školy, o jejích pracích popularizačních a přiležitostných, které promlouvají „konkrétní řečí $\mathrm{k}$ dobovým problémům a můžeme na nich, mimo jiné, nalézt i stopy vnitřního růstu autorky, složitého a nikterak bezproblémového“. Jiřina Popelová publikovala v roce 1970 ve Filosofickém časopise její nekrolog a obsáhlou bibliografii jejích prací. ${ }^{12}$ Rekapitulovala filosofickou práci A. Dratvové v oblasti filosofie a metodologie přírodních věd, ve výuce filosofie na středních školách a v oblasti, kterou nazvala antropologicko-etickou. Neopomněla ani její aktivitu ve vědeckých společnostech, zejména v Jednotě filosofické.

Dratvová byla obecně známa a oceňována především jako autorka prací z filosofie exaktních věd. Od počátku se však zajímala také o etickou látku,

\footnotetext{
8 A. Dratvová, Galileo Galilei, Česká mysl 36, 1942, č. 1, s. 1-7: 7.

9 A. Dratvová, Isaac Newton, Česká mysl 36, 1942, č. 4-5, s. 187.

10 Česká mysl 36, 1942, č. 1, s. 47.

11 K. Mácha, K sedmdesátinám Albíny Dratvové, Filosofický časopis 10, 1962, č. 3, s. 466.

12 J. Popelová, Za filosofkou Albínou Dratvovou, Filosofický časopis 18, 1970, č. 4, s. 695-701, bibliografie s. 701-703.
} 
i když eticky laděné studie začala vydávat až od konce 30. let a po 2. světové válce (Smutek vzdělanců, Etika tviorčí práce, Duše dnešní ženy, Hledání ztraceného kosmu). Uzavření českých vysokých škol na podzim roku 1939 a pozdější odchod do důchodu z místa referentky na ministerstvu školství a národní osvěty v roce 1942 přivedly Albínu Dratvovou k jiným tématům, především z oblasti etiky vědecké práce a psychologie. Její antropologické spisky jsou „moudrým návodem jak žít, jak snášet a přemáhat smutek života, jak si zajistit důstojnost vlastního já a osobní i nadosobní smysl své existence“. ${ }^{13}$

Jednou z nich byla úvaha Albíny Dratvové Smutek vzdělanců, která vyšla v edici Svazky úvah a studií. ${ }^{14}$ Sama uvádí, že myšlenka „každý myslitel má v tváři napsánu nejen vážnost, ale i smutek“ ji prvně napadla při prohlížení Descartova portrétu. V psychologicky laděném pojednání pátrá po povaze a příčinách nikoli „běžných“ smutků vyskytujících se v životě každého člověka, ale specifického smutku „opravdových vzdělanců“, tj. příslušníků „intelektuálními schopnostmi nejvyšších vrstev národư“ (nikoli u lidí, kteří procházejíce školami nenabyli hlubokého vztahu ke vzdělanosti). Takové vzdělance jí představují především vědci, ale i učitelé a úředníci; (překvapivě) stranou nechává umělce a (pochopitelně) státníky, politiky a vojáky. Domnívá se, že ten zvláštní smutek přepadá vzdělance hlavně proto, že u nich sféra rozumová, citová a volní nebývá v rovnováze; zejména vědce jejich přebujelá rozumovost přivádí $\mathrm{k}$ intelektualismu, neúměrné kritičnosti a sebekritičnosti, k nervové labilitě, skeptickému posuzování vlastní i vůbec lidské schopnosti dopracovat se pravdivého poznání, ke smutku z věčné omezenosti a relativnosti všeho vědění; citová a volní ochablost jim ztěžuje rozhodování, překonávání individualismu a navazování širších mezilidských kontaktů. Dratvová pátrá i po specifických zdrojích smutku učitelů a úředníků; uvažuje např. o vlivu zevšednění jejich činnosti, ale ovšem nezapomíná ani na všelidské problémy se „smyslem“ (práce, života, bytí vůbec) či „transcendentnem“. Vzdělancům jako lék proti smutku doporučuje především cílevědomou práci pro společnost, která jim zase může pomoci uznáváním a oceňováním

13 Tamtéž, s. 701.

14 Edice Svazky úvah a studii vznikla po 15. březnu 1939, na začátku německé okupace českých zemí a existence Protektorátu Čechy a Morava, aby čtenářmm přinášela nové poznatky z oblasti humanitních oborů, povzbuzovala jejich národní sebevědomí a důvěru v humanitní a demokratické ideály. Vydávalo ji pražské Nakladatelství Václav Petr, jejím iniciátorem a redaktorem byl František Kovárna, tehdy docent teorie a dějin výtvarného umění na Filosofické fakultě Karlovy univerzity. Jednotlivé svazky formátu $19 \times 12 \mathrm{~cm}$, s jednoduchou, ale výraznou obálkou v úpravě Jaroslava Švába, měly vycházet, jak se uvádělo v tiráži, v týdenních až čtrnáctidenních lhůtách a mít nejméně 32 strany. Do konce roku 1944 jich vyšlo 92. 
velkého dosahu jejich činnosti. ${ }^{15}$ Dušezpytné analýzy Dratvové se soustředují zejména na smutek související s lidským poznáním a lidskou činností. ${ }^{16}$

V letech 1939-1948 měla Dratvová v rozhlase pravidelné přednášky v pořadu Pưlhodina pro ženy. Uvažovala v nich o postavení žen, o jejich myšlení a aktivitách, o výchově dětí i o etických a společenských tématech. Z těchto přednášek vznikly některé knižní publikace, například Etika tvưrčí práce (1942) nebo Duše dnešní ženy (1947). Do svého deníku si Albína Dratvová zapsala už 31. prosince 1943: „... dnes jsem odevzdala Duši dnešní ženy. “ Knížka, na které pracovala od roku 1942 a jejímž základem byly rozhlasové přednášky, vyšla až po válce v červnu 1947, ale už v roce 1948 vyšlo její druhé vydání. ${ }^{17}$ Dratvová v ní nesporně navázala na své začátky. Byla na Filosofické fakultě žákyní Františka Čády a zřejmě i pod jeho vlivem vydala své první publikace - O stavech podvědomých a Freudově psychoanalyse (1921) a O tajich podvědomi (1925).

Dratvová v Duši dnešni ženy vychází výrazně z typologických postřehů. Přripomíná, že existuje celá řada pokusů o typologii žen, že o ni usilují především lékaři, ale přesto zůstává žena stále typologicky nedostatečně určena, protože duše ženy je svérázná a mnohostranná. Dratvová třídí ženy podle hlediska, které ji nejvíce zajímá a které se jí nejvíce hodí, a to podle jejich nadání a zájmu o to, co dělají. Její úvodní typologie dělí ženy na pykniky, organizátorky a ženy tvůrčí. Pykniky jsou celkem pasivní, jdou klidně životem, jsou dobrosrdečné a ohleduplné. Jsou konkrétní, obecného řešení nejsou schopny, je v nich kus ženské povrchnosti, bezprostřednosti, málo cílevědomosti a širšího rozhledu. Ženy organizátorky jsou vzdělané, pracují samostatně, uvědoměle, chtějí proniknout, uplatnit se, jsou praktické, reálné, nesentimentální, neromantické a pracovité. Zasloužily se o rovnoprávnost žen. Tvưrčí ženy jsou individualistky, vyrovnávají se mužům i v nejobtížnějších činnostech, v řízení podniků, v zákonodárné činnosti, ve všech duchovních aktivitách. Jejich rysy se projevovaly už v dětství a mládí. Jako ženy tvoří duchovní část společnosti, v myšlení jsou samostatné, společnosti se nikdy plně nepřizpůsobují.

V proudu času sleduje Dratvová nejen proměny společenského postavení žen v 19. a 20. století, ale také vytváření charakteru, povahy a osobnosti především žen. Věnuje se krizi třicetiletých, která je krizí prchajícího mládí a projevuje se zejména u žen bezdětných metafyzickou hrůzou z prázdnoty.

15 Dratvová končí výzvou ke vzdělancům i prostým lidem: „Odstraňujte intelektualismus jako přežitek, ale nepotlačujete a nepodceňujte intelekt, rozum, to nejvyšší, co lidský rod má!“

16 J. Popelová, Za filosofkou Albínou Dratvovou..., s. 698.

17 A. Dratvová, Duše dně̌ni ženy, 2. vyd., Praha: Československý kompas 1948. 
Je ale příležitostí k vytvoření nového vztahu k životu. Překonat ji lze skromností a úsilím, následujících deset let je nejkrásnějších, vytváříme nejvíce hodnot, je to doba tvůrčí a pracovní schopnosti, nejlepších nápadů, kdy „se žena uklidnila, zvítězila nad velkými překážkami, našla samu sebe, našla své sebevědomí ${ }^{18}$ Dratvová odmítá chápat padesátku jako pouhý most do stáří, jako přelom a nenapravitelně horší stav, než byl ten dosavadní. Žena se musí „rozumně vyrovnat $\mathrm{s}$ jistotou, že v tomto věku už není mladá, přizpůsobit se tomu a hledat nové, přiměřené, rozumné pole nové činnosti““ ${ }^{19}$ Proti idealizovanému obrazu krásného stáří staví Dratvová skutečnost, kdy „lidské slabosti stáří se ukazují na přečetných stařenách: lpění na minulosti téměř výhradně, lakota, sobectví a autoritářství“. ${ }^{20}$

V ženách všech typů pak Dratvová vymezuje několik základních znaků schopnost uchovávat hodnoty (na kterou stále klade velký důraz), citovost, individuálnost, konkrétnost až praktičnost myšlení a jednání. Dratvová sleduje chování a reakci žen na přítomné, minulé a budoucí dění. Prožívání jednotlivých dob je podle ní u žen velmi osobní, protože ženy jsou bytosti silně citové. Mnoho žen je zcela obráceno do minulosti, jsou to konzervativní bytosti, které tvrdošíjně obdivují staré časy a věci a ztrácejí smysl a cíl svého přítomného života. Opačným extrémem jsou ženy zahleděné jen do budoucnosti. Dratvová je dělí na čtyři typy - pasivní optimistky, které se těší na to, co přinese budoucnost, ale nepřipravují se na ni, pasivní pesimistky, které se budoucnosti bojí, ale nedělají nic, aby ji změnily, aktivní optimistky, které žijí nadějemi a přípravou na budoucnost, a konečně aktivní pesimistky, které mají obavy z budoucnosti, pracují s myšlenkou, že budoucnost je zrádná, pomíjející a nejistá. Třetí druh žen žije a plně stojí v přítomnosti. Tyto ženy nejsou zatíženy ani minulostí, ani obavami z budoucnosti. Jejich nebezpečím je povrchnost, snaha pouze užívat si př́ítomnosti.

Dratvová ukazuje, jak se tyto typy žen mohou realizovat. Žena, která tkví v minulosti, může být strážkyní tradice, dobrého jména rodiny, českého umění, českého jazyka, české literatury a české hudby. Ženy duševně dozrávají, dotvářejí svou osobnost. Ženám orientovaným do budoucnosti může naděje na budoucnost pomoci z nervozity, neklidu a strachu. Dratvová vyzývá, abychom se postavili „na jedině pevnou půdu skutečnosti, a tou je přítomný

$\begin{array}{ll}18 & \text { Tamtéž, s. } 36 . \\ 19 & \text { Tamtéz̆, s. } 37 . \\ 20 & \text { Tamtéz̆, s. } 46 .\end{array}$ 
život “. ${ }^{21} \mathrm{Je}$ přesvědčena, že nejlépe se $\mathrm{s}$ prožíváním minulosti, přítomnosti a budoucnosti vyrovnávají ženy tvořivé, ženy nadané tvůrčími schopnostmi.

Velmi zajímavá je snaha Dratvové pronikat do ženina žitého času „s jeho specifickou atmosférou v různých životních obdobích“, ${ }^{22}$ kterými jsou smutek mládí, smutek po třicetinách a nejtěžší smutek starých žen, který je beznadějný. „Za psychologií cítíme v pozadí filosofku, která za povrchovými jevy tuší metafyzická tajemství lidské existence. Vztah ženy a žitého času zachycuje nejen v ženiných proměnách v toku jejího zrání a uvadání, ale i v ženině vztahu k času, k jejímu připoutání k minulosti vazbou neodbytných vzpomínek, nebo naopak v sepětí s přítomností nebo zaměření na budoucnost.“23

Dratvová se obsáhle zamýšlí nad smyslem rodiny, nad jejími účely a posláními. Tím prvním je účel biologický, dalšími řádná výchova dětí, právní povinnosti, národohospodářský význam, sociální poslání i státně politické úkoly. „K tomu je potřebí vzdělaných, uvědomělých žen. “24 Dratvová konstatuje, že nemůže „podat konečné řešení základních otázek o smyslu rodiny“. ${ }^{25}$ Nelze totiž definovat, co rozumíme nejvyšším, nejhlubším, filosofickým, metafyzickým smyslem rodiny, vyřešit, „proč lidé zakládají rodinu, proč vstupují do manželství, proč rodina je nejpevnější jednotkou společnosti a proč dává tolik štěstí, podle mnohých myslitelů největší štěstí vůbec““. ${ }^{26}$

Poměrně obsáhle se Dratvová zabývá krizí rodinného života. Navazuje zde tematicky na In. A. Bláhu a jeho práci Dnešni krize rodinného života (1933). Ukazuje jednotlivé stránky krize - biologickou, sociální, právní, hospodářskou i světonázorovou. Navíc „dnešní život, přeskakující těkavě od zájmu k zájmu, dychtivý ohlušování vnějšími prostředky, příliš věcný a citově chladný“ se projevuje „v nespokojenosti, v hledání zapomenutí všemi prostředky, často nevybíravými a mnohdy i škodlivými“". ${ }^{27}$

Jedním z negativních následků krize rodiny a její myšlenkové, citové a volní nejednotnosti je podle Dratvové špatná výchova dětí. Toho si byli vědomi i mnozí pedagogičtí reformátoři v minulosti, a proto žádali odstranění vlivu rodiny na výchovu dětí a výchovu internátní. Další překážkou dobré výchovy

21 Tamtéz̆, s. 62.

22 J. Popelová, Za filosofkou Albínou Dratvovou..., s. 698.

23 Tamtéž, s. 700.

24 A. Dratvová, Duše dnešní ženy..., s. 70.

25 Tamtéż, s. 71.

26 Tamtéż, s. 72.

27 Tamtéz̆, s. 77. 
dětí může být i nesoulad v širším příbuzenstvu, v jeho úrovni vzdělání, zájmech a povahách. Výchovné vlivy se rozšiřrí a zkomplikují vstupem dítěte do školy a setkáním s širší společností, se životem. Krize výchovy má podle Dratvové „tři hluboké kořeny: 1. úpadek logického myšlení; 2. nedostatek sjednocujících idejí; a 3. nedostatek osobností, schopných sjednotit výchovu“.28

Dratvová prosazuje přesné a jasné myšlení, protože „příliš pevně se v nás usadila myšlenka, že každý má svou pravdu a že proto jiné mínění není ani dokazatelné, ani vyvratitelné. Toto úpadkové myšlení, nemorální ve své podstatě, podobá se úpadkové sofistice starého i středního věku. $\mathrm{S}$ tím rozdílem, že tehdy se zneužívalo logických forem, kdežto dnes se jich nedbá“ “. ${ }^{29}$ Velmi kriticky se Dratvová vyjadřuje ke stavu pedagogiky. Rodiče ztrácejí autoritu. Před emancipací byly ženy vychovávány v romantické přecitlivělosti, důraz se kladl na pěstování estetického cítění, sentimentalitu a př́ijemné chování jako záruky pravé ženskosti. Sentimentální výchova byla vystřídána intelektualismem, přílišným vzděláváním rozumu. Tento intelektualismus je střídán voluntarismem, výchovou k rozhodnosti, ke schopnosti jednat a být odpovědni. Škola se má osvobodit od přemíry vědomostí. Dratvová poměrně překvapivě doporučuje překonat nejednotnost výchovy společným internátním vychováváním a vzděláváním.

Zvláštní pozornost věnuje Dratvová výchově a charakteru dcer (dívek) jako příštích žen. Je to podle ní úkol matek, kterým se tradičně připisuje schopnost (pud) rozumět vlastním dětem. U toho se ale nemá zůstávat, tento pud je třeba zušlechtovat rozumem a teoretickými vědomostmi o výchově. Překážkou výchovy dcer je ženina citová zranitelnost. Úspěšnost výchovy závisí na získání výchovné autonomie a na schopnosti sebevýchovy. Stejně tak je třeba dívky vést $\mathrm{k}$ sebeúctě, odpovědnosti a skromnosti. Jednou z důležitých oblastí výchovy dívek se stává výchova národohospodářská. Přitom již víme, že nejzákladnější funkcí ženy v soudobém životě je funkce ženy jako uchovatelky hodnot, hmotných a duchovních. To je podle Dratvové ženám dáno, nemusejí se tomu učit, zatímco k národohospodářskému myšlení, které přinesla až současná doba, se musí žena vychovat a připravit. Od ženy se očekává, že bude dobrou domácí hospodářkou, ale je žádoucí, aby se postupně zapojila i do širších hospodářských souvislostí. Zde překoná žena rodinný rámec a stává se součástí ekonomických struktur, její chování a jednání je podrobováno kritickému pohledu veřejnosti. Tento pohled se tradičně opírá o srovnávání ženina myšlení, cítění a jednání s muži. 
Dratvová vychází z odlišnosti ženského a mužského myšlení. Domnívá se, že běžné ženské myšlení se nejvíce liší od myšlení mužského „ve schopnosti myslit o nenázorných věcech (zvláště pojmech), v důslednosti a ve schopnosti postupovat spojitě od jednoho výroku k druhému. Nejnápadněji se jeví tyto rozdíly $\mathrm{v}$ poměru $\mathrm{k}$ matematice a $\mathrm{k}$ vědám, které souvisí a závisí na matematickém myšlení“ “ ${ }^{30}$ Dratvová sleduje přístup dívek a žen k matematice na různých stupních škol a konstatuje, že ženám chybějí matematické schopnosti, zejména schopnost abstraktního myšlení, myšlení důsledného a rovněž matematická tvořivost. Ženy vyžadují, aby si mohly názorně představit to, o čem přemýšlejí, diskursivní myšlení je jim vzdáleno, je jim nejvlastnější myšlení intuitivní, nápadové, přesahující některé články posloupnosti, nejsou dost trpělivé. „Ženské myšlení nemajíc namnoze pevných směrnic logických, bývá často ovládáno pouhým asociativním vázáním myšlenek, podnícených citem. Odtud plynou její nepředvídatelné obraty v myšlení i nepředložené činy, k jejichž porozumění je třeba znát tuto zvláštnost ženina myšlení. “31 A. Dratvová se však současně domnívá, že „praktický, neschematický, konkrétní způsob ženina myšlení má mnohé přednosti, které ženu přivádějí blíže k životu než muže“, 32 a ptá se, jak se chovají ženy v různých životních situacích. Proti údajně př́liš specializovaným mužům disponují celistvostí postřehu, proti mužské těžkopádnosti se hodí ženino intuitivní a praktické řešení, dokáží vystihnout charakterové vlastnosti posuzovaného člověka, jsou schopny soustředit se na přítomný děj a nezatěžovat se důsledky.

Mnohé ženy se zaměřují na přítomnost, a tím zapomínají na všechno ostatní. Zatímco muži jsou př́lišs spjati se svým povoláním a po odchodu do důchodu si nevědí rady s volným časem, ženy se lépe přizpůsobují změněným podmínkám, jsou otevřené novým zkušenostem a novinkám, rády experimentují. Muži mají v běžném životě rádi klid a pravidelný život, experimentují ve vědě, umění a v pracovní činnosti.

Dratvová používá další typologii žen - nejvýše staví ženu klidnou, tvořivou, která obtíže snáší s humorem, žije ve světě rozumu. Jiný typ je žena kritická, která vidí na všem chyby a překážky, je pesimistická, náladou melancholická, šírí neklid a smutek. Další typ je žena uhýbavá, která je sice noblesní, ale vyhýbá se jakémukoli rozhodování a změnám. Na otázku, co žena očekává od života, odpovídá Dratvová, že je to splnění snu o štěstí. Čím je rozumná

30 Tamtéž, s. 106.

31 Tamtéž, s. 111-112.

32 Tamtéž, s. 113. 
žena starší, tím méně toho od života očekává, až nakonec neočekává od života nic. Jinou otázkou je, co chtějí muž a žena životu dát a co mu dovedou dát. Dratvová konstatuje, že dnešní život má mužskou pečet. I práce žen dostala mužský charakter, a proto doporučuje počkat, až se ženské hodnoty v životě prosadí. Ženy už dosáhly značných úspěchů v politice a pronikly na přední místa ve všech oborech. Účast žen v politice vyžaduje nejen vzdělání v řadě relevantních oborů, ale také schopnost žen ukáznit se a odosobnit, aby se žena „nedala strhnout svým temperamentem, svou tělesnou slabostí, rodinnými nebo mateřskými starostmi a osobními nechutěmi“. ${ }^{33}$

Dratvová mezi ženské vlastnosti klade „citovou vznětlivost ke kladení mnoha otázek“. ${ }^{34}$ Př́íčinou je „neklidný, namnoze neukázněný způsob ženského myšlení, řídící se spíše asociativním sdružováním představ než logickým spojováním pojmů“. ${ }^{35}$ Dratvová se věnuje ženskému individualismu, který pokládá za typicky ženskou vlastnost vedle povídavosti a citovosti. Ta se projevuje nedůtklivostí ke kritice, podléhání společenským citům, zvláště lásce, činy motivovanými city. Důležité místo v životě žen má práce, ženskou výhodou je podle Dratvové pracovitost a schopnost se zapracovat v kterémkoli oboru. Přitom ženská práce spojená s rodinným životem je stejně hodnotná jako veřejné povolání. Citlivou a přitom zásadní otázkou je pro Dratvovou tvůrčí nadání žen. Všímá si kritických ohlasů na výsledky tvưrčí činnosti žen spisovatelek a výtvarných umělkyň. Jejich práce podle kritiků nemají koncepci a strukturu, rozbíhají se do podrobností, které jsou pro ženy typické (zvyky, oděvy, rodinné prostředí), dovedou psát jen o sobě a své rodině a nejsou dost objektivní. Přitom je Dratvová pevně přesvědčena, že ženy jsou tvưrčí práce schopny. Oceňuje nejen jejich velké tvưrčí činy, ale také ženinu tvořivost „běžného života“: „Její tvorba záleží v tom, že z mála dovede vytvořit mnohé, lepší a rozmanitější, než jí byl dán materiál. Její čilý duch kombinuje, namáhá se, konstruuje nové, vhodnější možnosti a raduje se ze zdaru práce.“36

Nejkrásnějším a nejobecnějším lidským citem je podle Dratvové štěstí, vnitřní spokojenost. Má různé formy, je to zvláštní stav mysli, který přináší radost, spokojenost, chut k práci a víru v budoucnost. Nelze ho nahrazovat zábavou ani pouhým sněním nebo vnějšími, často relativními a dočasnými úspěchy. Cesta ke štěstí má několik podmínek, předpokladů: První je schopnost

33 Tamtéž, s. 124.

34 Tamtéž, s. 125.

35 Tamtéž, s. 125-126.

36 Tamtéž, s. 164. 
zbavit se zábran jako jsou marnivost, ješitnost, strach před veřejným míněním a předsudky veřejnosti, negativismus ve vlastní povaze (být kladným člověkem), pocit méněcennosti, schopnost sebekritického posouzení vlastních schopností. Druhou podmínkou štěstí je síla zájmů. Zájem je trvalá pozornost k věcem a schopnost ji trvale udržet a podřizovat nižší zájmy vyšším. Třetí podmínkou je „schopnost poznat své místo na světě, snažit se dospět k němu, dospět vnitřní svobody, milovat život a sloužit životu“. ${ }^{37}$ Dratvová vyzývá, aby se lidé zbavili sobectví a byli schopni práce pro celek. „Žena, žijící v rodině, má tento úkol práce pro celek obzvláště usnadněn. Pracuje pro celek nejmenší, ale základní, pro svou rodinu. Zdaříli se jí, aby přivedla své děti k práci pro další celky, aby se dovedly pro celek i obětovat, vykonala kus úctyhodné práce. V tomto pomyšlení se osobní štěstí matčino rozšiřuje v štěstí nadosobní, - i prostá žena se proměňuje v bytost vyšší, - a lze si myslit něco většího?“38

Úvahy Albíny Dratvové o duši dnešní ženy nemají pouze filosofickou povahu, ale zasahují i do sociologie, pedagogiky a psychologie. Jejich společným východiskem a vyústěním je hluboké přesvědčení o rostoucí významné roli žen ve společnosti. Dratvová důvěřuje odpovědně jednajícím, vzdělaným a tvưrčím ženám a přikládá velký význam mravním hodnotám a mravní výchově.

Albína Dratvová zemřela v domově důchodců v Terezíně 1 . prosince 1969 ve věku 77 let. Svou pozůstalost předtím v roce 1961 předala do Archivu ČSAV. ${ }^{39}$ Jak uvádějí editorky jejího deníku, „dokumenty z posledních let života v Terezíně odnesla Vltava za stoleté povodně v roce 2002 “. ${ }^{4}$

Přispěvek vznikl jako součást řšeni projektu GA ČR Ženy v české filozofii a vědě (GA17-06697S).

\section{prof. PhDr. Jan Zouhar, CSc.}

Katedra filozofie, Filozofická fakulta, Masarykova univerzita

Arna Nováka 1, 60200 Brno, Česká republika

zouhar@phil.muni.cz

37 Tamtéž, s. 181.

38 Tamtéž, s. 185.

39 Osobní fond Dratvová Albína je tam uložen s evidenčním číslem NAD 281.

40 Klára A. Čápová - Liboše Heczková - Zuzana Leštinová, Předmluva, in A. Dratvová, Denik 1921-1961. Scientific Diary..., s. 14. 